Annals of Plant Sciences

ISSN: 2287-688X

OPEN ACCESS

Reaseach Article

www.annalsofplantsciences.com

\title{
Spoil characteristics under five years old native woody plantations and unplanted dump in dry tropical environment, India.
}

\author{
A.N. Singh \\ Department of Botany, Panjab University, Chandigarh-160014, India
}

Received: 9/22/2017; Accepted: 9/28/2017

\begin{abstract}
Present study was conducted to investigate spoil characteristics under 5-yr old high-density plantations of three native trees (Albiria lebbeck. A. procera and Tectona grandis) and one fast growing woody grass (Dendrocalamus strictus) species on coal mine spoils and same age unplanted mine spoil dump at the same area. We examined physical characters such as soil bulk density, water holding capacity, soil texture (sand, clay and silt) and chemical characters such as $\mathrm{pH}$, total nutrients $(\mathrm{C}, \mathrm{N}$ and $\mathrm{P}$ ) and exchangeable cations $(\mathrm{Ca}, \mathrm{Mg}, \mathrm{K}$ and $\mathrm{Na})$ in chronosequence of spoil depth $(0-50 \mathrm{~cm})$ at $10 \mathrm{~cm}$ interval under planted stand of each selected species and unplanted dump. A significant effect of plantations on physico-chemical characteristics (except soil bulk density) of mine spoils was found. Among species, $A$. lebbeck, exhibited substantial improvement in mine spoil soils followed by D. strictus, A. procera and T. grandis plantation. Although, chemical characteristics especially total concentrations of soil $\mathrm{C}, \mathrm{N}$ and $\mathrm{P}$ and their ratios were significantly different due to species and spoil depth, indicating plantations of all species have abilities to improve soil chemical qualities at young stage of establishment. Compared to unplanted dump, plantation of $A$. lebbeck showed highest concentrations of total nutrients $(C, N$ and P) and exchangeable cations with respect to spoil depth followed by D. strictus, A. procera and T. grandis, which confirms that some species have suitable qualities for the modification of spoil characteristics during rehabilitation process.
\end{abstract}

Keywords: Albizia lebbeck; Albiqia procera; Dendrocalamus strictus; Tectona grandis; unplanted dump, UPD; Mine spoil.

\section{Introduction}

Coal extraction by surface mining (opencast) process drastically alters the physical and biological nature of the surroundings of mined area (Singh et al. 1995; Frouz et al. 2017). On the first hand, this industry is to the next of agriculture that posses a significant role to meet our demands in different ways. Most of the natural wealth of the world, for example, precious metals (diamond, silver and gold), comes out through mining activities. But on the other hand, the process of opencast mining posed serious environmental problems which left damaged landscapes, disrupted ecosystems and destroyed microbial communities that are to be a hard task to restore into their original state (Singh et al. 1995; Bradshaw 2000; Singh et al. 2004a; Vega et al. 2005; Jozefowska et al. 2017).

The most important preconditions for ecosystem rehabilitation in post mining landscapes are the processes of soil redevelopment (Singh et al. 2004a,b; Sourkova et al. 2005; Singh et al. 2006; Liu et al. 2017). The soil has to be restored in these landscapes with all physico-chemical and biological properties such as texture, bulk density, water holding capacity, $\mathrm{pH}$, exchangeable cations, total nutrient content and availability as well as microbial nutrients and its activity. Once soil fertility is restored, it will be easier for the more desirable species to establish and perpetuate into self sustained ecologically suited design, therefore, soil is considered to be one of the primary agents in determining vegetation development and the importance of soil characteristics in ecological studies cannot be underemphasized (Singh et al.

\section{${ }^{*}$ Corresponding Author:}

Dr. Anand Narain Singh,

Assistant Professor, Department of Botany,

Panjab University, Chandigarh-160014, India.

E-mail: dranand1212@gmail.com 2004b; Singh and Singh, 2006). Since mine spoils are characterized by the loss of soil both in pedological and biological sense. Restoration of such degraded lands is a challenging ecological problem. Moreover, natural recovery in mine spoils is a slow process (Singh et al. 1995). A successful restoration programme attempts to accelerate the natural recovery processes to check the soil erosion, to restore the soil fertility and to enhance the biological diversity (Singh et al. 2002). The first step in any restoration programme, of course, is to protect the disturbed habitat and communities from being further wasted. Then follow attempts to accelerate the revegetation process for increasing biodiversity and stabilizing nutrient cycling (Singh et al. 1995). If planting a desirable plant species on mine spoil can accelerate the process of natural succession, a self-sustaining ecosystem may develop in a short period.

Evidently, Fisher (1995) suggested five general hypotheses for the mechanisms that contribute to the amelioration of degraded lands by planting certain desirable species. The mechanisms involve: first, an increase in the soil organic matter contents as a result of carbon (C) fixation in photosynthesis and its transfer via leaf litter and root turnover to the soil. Second, nitrogen $(\mathrm{N})$ fixation by some leguminous trees results in an increase in soil $\mathrm{N}$ content under the tree canopy. Third, a rhizosphere effect of tree on soils resulting in enhanced $\mathrm{N}$ mineralization and increased microbial biomass. Fourth, microclimate modification by tree canopies that moderate soil and air temperatures and soil 
moisture regimes, and fifth, nutrient pumping reflecting uptake of nutrients from greater depths by tree roots and accumulation in a smaller volume of surface soil as a result of litter fall.

In agreement with this, Singh and Singh (1999) reported that a desired species for planting on mine spoils should possess the abilities (i) to grow on poor and dry soils, (ii) to develop the vegetation cover in short time and to accumulate biomass rapidly, (iii) to bind soil for arresting soil erosion and checking nutrient loss, and (iv) to improve the soil organic matter status and soil microbial biomass, thereby enhancing the supply of plant available nutrients. In addition, the species should be of economic importance. On the basis of the effectiveness of above these facts, four species were chosen for plantation in this study: Albizia lebbeck (L.) Benth.; A. procera (Roxb.) Benth; Tectona grandis (L. f.); and Dendracalamus strictus (Roxb.) Nees. The selected species are indigenous and possess varied ecological characteristics such as short stature leguminous tree (A. lebbeck, $A$. procera), slow growing timber tree (T. grandis) and fast growing woody grass (D. strictus). Earlier reports on the same plantations evidently proved that certain ideal species have positive tendency to improving soil nutrient level in coalmine spoil. For example, bamboo plantations showed a significant effect on redeveloping soil of coal mine spoil in terms of high rate of accumulating biomass, productivity, litter fall and microbial biomass within a short time (3-5 years) (Singh and Singh, 1999). Rest three planted species (A. lebbeck, A. procera and T. grandis) also showed a substantial role in the same direction within a short period (4-6 years) (Singh et al. 2004a, 2004b).

Mine spoil habitats often show heterogeneity condition especially in soil nutrient distribution (Bloomfield et al. 1982); and spoil material does not contain organic $\mathrm{C}$ derived from recent plant material, but may contain various amounts of fossil C (Barnhisel and Massey, 1969; Roberts et al. 1988). In addition, adverse properties of spoil material, such as erosion, toxicity and unsuitable water regime or nutrient deficiency, may reduce plant growth in some post-mining landscapes (Bradshaw and Huttel, 2001; Sourkova et al. 2005). Therefore, questions might be arrived such as: (1) are these planted species can rapidly change physico-chemical properties into deeper depth of mine soil (up to 50 $\mathrm{cm})$ or only in the mineral layer $(0-10 \mathrm{~cm})$ of spoil? (2) Does the role of leguminous substantially differ from non-leguminous species especially in $\mathrm{C}$ and $\mathrm{N}$ nutrients in soil of mine spoil? (3) Does variability in physico-chemical properties across soil depth and species exhibiting any trend to understand soil restoration mechanism at least from initial stage of rehabilitation?
Therefore, in present study, we compared the effect of 5-year old planted species with naturally vegetated same age unplanted coal mine spoil dump (UPD) on certain soil physico-chemical characters such as water holding capacity, bulk density, soil texture (sand, silt and clay), $\mathrm{pH}$, total nutrients (C, $\mathrm{N}$ and $\mathrm{P}$ ) and exchangeable cations ( $\mathrm{Ca}, \mathrm{Mg}, \mathrm{K}$ and $\mathrm{Na})$ under chronosequence of spoil depth (0-50 $\mathrm{cm})$. In this study, climate, relief, parent materials and time were same for unplanted dump and all plantations, respectively. Therefore, differences found between the soil characters would be comparable due to the effect of vegetation.

\section{Materials and Methods}

\section{Description of Study Site}

The plantations were situated in the east section of Jayant Block which is located in the North-eastern part of Singrauli Coalfield in the district of Sidhi (Madhya Pradesh, India) between latitudes $24^{\circ} 6^{\prime} 45^{\prime \prime}-24^{\circ} 11^{\prime} 15^{\prime \prime} \mathrm{N}$ and longitudes 82'36'40"$82^{\circ} 41$ '15”E. Due to opencast coal mining operations in the area, huge amount of overburden materials are dumped on adjacent lands. Dump management in this area includes filling of void by overburden. Overburden removed by shovel dampers is dumped over the internal dumps created by draglines and subsequently leveled by dozers. The periphery of the overburden dump is kept sloped at $28^{\circ}$ with maximum bench height of $30 \mathrm{~m}$. The rocks are fine to coarse-grained sandstones, white and gray clays with ferruginous bands, carbonaceous shale and coal seams (Singh et al., 1995).

The climate of the area is tropical monsoonal and the year is divisible into a mild winter (NovemberFebruary), a hot summer (April-June) and a warm rainy season (July-September). Data collected at a meteorological station present on the site showed that the mean monthly minimum temperature within the annual cycle ranges from $6-28^{\circ} \mathrm{C}$ and mean monthly maximum from $20-40^{\circ} \mathrm{C}$. The annual rainfall averages $1069 \mathrm{~mm}$, of which about 90\% occurs during late June to early September (Singh et al., 1995; Singh and Zeng, 2008).

\section{Plantations and Sample Plots}

All the plantations were raised in the month of JulyAugust by planting nursery-raised seedlings in previously dug pits of $40 \mathrm{~cm} \times 40 \mathrm{~cm} \times 40 \mathrm{~cm}$ size at a spacing of $2 \mathrm{~m} \times 2 \mathrm{~m}$. Plantations of $A$. lebbeck and $A$. procera were raised by planting 7 to 8 months old nursery raised seedlings on east section of mine spoil. Plantation of $T$. grandis was raised by planting 6 to 8 months old nursery-raised seedlings on west section of mine spoil dump. While $D$. strictus plantation was raised by planting eight months nursery-raised seedlings on east section of mine spoil dump. UPD was situated in the east section that is very near to all selected plantations. It had 
been remained as it is only for comparison, regarded as control site. Total planted area for $A$. lebbeck and $A$. procera was $1.5 \mathrm{ha}$, each, whereas the same for $T$. grandis and D. strictus was about 0.5 ha, each. In case of UPD, the total area was 0.4 ha. For sampling three permanent plots were established for each species.

The size of the sample plots was $25 \mathrm{~m} \times 25 \mathrm{~m}$ for $A$. lebbeck and $A$. procera, and $15 \times 15 \mathrm{~m}$ for $T$. grandis and $D$. strictus and $10 \mathrm{~m} \times 10 \mathrm{~m}$ for UPD. At UPD site, a total of 30 herbaceous species representing 12 families was recorded. Beneath plantations, a lower number of species representing 10 families as from UPD site was recorded, being maximum in $T$. grandis (24) and minimum in $D$. stricus (12) plantation plots. While in case of both legume plantations (A. lebbeck and $A$. procera) the number of herbaceous species representing 8 families was somewhat similar. However, following species Aristida adscensionis, Bothriochloa pertusa, Dactyloctenium aegyptium, Tephrosia perpurea and Cassia tora were the most abundant species in the ground vegetation among all plantations as well as in UPD site (Singh, 1999). However, detail study regarding biodiversity reconstruction, rate, species richness, evenness and their association under all native and exotic woody species planted on coal mine spoil is however still under investigation.

\section{Sample Collection and Analyses}

Soil samples were collected at random from each of the three permanent plots of each species including UPD using $15 \times 15 \times 10 \mathrm{~cm}$ monoliths for $0-50$ spoil depth at $10 \mathrm{~cm}$ interval. Six monoliths soil samples collected from within a plot were separated according to the depth variation $(0-10,10-20,20-30$, $30-40$ and $40-50 \mathrm{~cm})$ then thoroughly mixed to yield one composite sample per plot separately for each soil depth; this yielded fifteen samples for each plantation. Large pieces of plant materials were removed and the field-moist soil was air dried, sieved through a $2 \mathrm{~mm}$ mesh screen, and then used for any physico-chemical analysis.

Water holding capacity was determined using perforated circular brass boxes (Piper 1944). Soil bulk density was determined by using soil corer and measuring the weight of dry soils of a unit volume to each spoil depth at $10 \mathrm{~cm}$ interval (Piper 1944). Particle-size distribution (texture) was analysed by using soil sieves of different mesh sizes (Piper 1944). Soil $\mathrm{pH}$ was measured in a 1:2.5 mixture of soil and de-ionized water using a glass electrode. Soil organic C was determined by dichromate oxidation and titration with ferrous ammonium sulphate (Allen et al., 1986). Kjeldahl $\mathrm{N}$ was determined by microkjeldahl method (Jackson 1958), and samples were analysed for total P by a phosphomolybdic acid blue colour method after triple acid digestion (Jackson 1958). For the analysis of total $\mathrm{Ca}, \mathrm{Mg}, \mathrm{K}$ and $\mathrm{Na}$, spoil soil was digested in the triple acid mixture as above (Allen et al., 1986). Total $\mathrm{Na}, \mathrm{Mg}$ and $\mathrm{K}$ were measured by using a flame photometer (Systronics Mediflame 127) and Ca by a Perkin-Elmer atomic absorption spectrophotometer (373 AAS) following Allen et al., (1986).

\section{Statistical analyses}

All the statistical analyses were done using SPSS-PC statistical software (SPSS, version 14.0). To observe effects of species and spoil depth on physicochemical properties of coalmine spoils, the data were subjected to analyse analysis of variance (ANOVA) through multivariate factorial analysis by general linear model (GLM). Species and spoil depth were used as a main fixed factor and all data for physico-chemical properties were in dependent variables.

\section{Results and Discussion}

Effect of Physical Characters on mine spoil Bulk Density and Water Holding Capacity

Bulk density is a measure of the weight of the soil per unit volume, usually given on an oven dry basis. It is used as a measure of soil wetness, volumetric water content, and porosity. It is also a measurement of the compaction of the degree of compaction of the soil. In this study, the bulk density values showed an increasing trend with increased spoil depth $(0-50 \mathrm{~cm})$ but were not significantly different among species and UPD at 0 $50 \mathrm{~cm}$ spoil depth, being maximum in UPD $(1.76 \mathrm{~g}$ $\left.\mathrm{cm}^{-3}\right)$ at $30-40 \mathrm{~cm}$ and minimum in A. lebbeck $(1.60 \mathrm{~g}$ $\left.\mathrm{cm}^{-3}\right)$ and $T$. grandis plantation $\left(1.60 \mathrm{~g} \mathrm{~cm}^{-3}\right)$ at $0-10$ $\mathrm{cm}$ spoil depth (Fig. 1a; Table 1). However, in UPD site, bulk density values (1.61 $\left.\mathrm{g} \mathrm{cm}^{-3}\right)$ were somewhat in similar range as it was found in $A$. lebbeck and T. grandis plantation $\left(1.60 \mathrm{~g} \mathrm{~cm}^{-3}\right)$ at $0-20$ $\mathrm{cm}$ spoil depth; but subsequently become higher $\left(1.72-1.76 \mathrm{~g} \mathrm{~cm}^{-3}\right)$ when progressively down spoil profile from $20-50 \mathrm{~cm}$ (Fig. 1a). Evidently, corresponding values $\left(1.75 \mathrm{~g} \mathrm{~cm}^{-3}\right)$ reported in fresh mine spoil (Singh et al., 2004a) was above the threshold value as reported by Russell (1977) that root growth is restricted in soils with a bulk density higher than $1.6 \mathrm{~g} \mathrm{~cm}^{-3}$. Soil bulk density may vary due to textural differences, organic matter content, and cultivation practices (Hausenbuiller 1981). Clay, clay loam, and silt loam soils normally have bulk densities ranging from $1.00-1.60 \mathrm{~g} \mathrm{~cm}^{-3}$ and a range of $1.20-1.80 \mathrm{~g} \mathrm{~cm}^{-3}$ may be found for sand and sandy loams. After establishment of $A$. lebbeck and T. grandis plantation, this value became lower than fresh mine spoil and UPD, while in case of $A$. procera and $D$. strictus plantation the values were lower than fresh mine spoil, but were still higher than threshold value of $1.60 \mathrm{~g} \mathrm{~cm}^{-3}$ for better root growth. Although, plantations of native woody species had significant impacts on the physical condition of the mine spoil, the trees had kept the 
ground covered and reduce evaporation (Singh et al., 1995; Singh et al., 2002). However, the plausible reason for the higher values of soil bulk density with increasing spoil depth might be due to the loosely compaction, heterogeneous mixture of stone and rock fragments, deflocculated soil particles and restricted capillary pores (Singh et al., 1995; Frouz 2017). In agreement with this, however, Bending \& Moffat (1999) reported that bulk density commonly exceeded $1.70 \mathrm{~g} \mathrm{~cm}^{-3}$ below $20 \mathrm{~cm}$ depth in mine spoil. Delong et al., (2012) have estimated corresponding parameters by four methods under reclaimed rocky mine spoils from Kanawha County, West Virginia, USA reported bulk density under compacted and non-compacted mine soil within range of our study. They further documented that sandstone mine soils, with different compaction degrees, gave similar bulk density values of 1.70 to $1.84 \mathrm{Mg} \mathrm{m}^{-3}$. The native forest soil had a bulk density of $1.05 \mathrm{Mg} \mathrm{m}^{-3}$.

Other physical properties such as water holding capacity showed a significantly increasing trend with respect to spoils depth thus values were substantially higher among different plantations compared to UPD (Fig. 1b; Table 1), being maximum in $A$. lebbeck $\left(400.9 \mathrm{~g} \mathrm{~kg}^{-1}\right)$ at $40-50 \mathrm{~cm}$ spoil depth and minimum in UPD $\left(215.2 \mathrm{~g} \mathrm{~kg}^{-1}\right)$ at $0-10 \mathrm{~cm}$ spoil depth (Fig. 1b). Therefore, analysis of variance (ANOVA) indicated significant differences due to species and depth but their interaction (species $\times$ spoil depth) was not significant varied (Table 1). Perhaps, plant growth on spoils may be limited due to lack of available moisture (Sutton \& Dick 1987; Zhou et al., 2017). Spoil materials often have reduced water infiltration and water holding capacity compared to un-mined soil. In the present study, significant improvement in water holding capacity of the soil was observed as a result of establishment of plantations. This improvement was maximum in the case of $A$. lebbeck and $A$. procera plantations. Toy and Shay (1987) argued that water holding capacity of the soils could be higher due to an increase in silt and clay contents. In agreement with this, plantation of $A$. lebbeck resulted higher percentage of silt while $A$. procera resulted higher clay contents compared to other plantations. Therefore, the plantations of both $A$. lebbeck and $A$. procera reflected higher quantity of water holding capacity in the soil.

\section{Particle Size Distribution}

Like bulk density, soil texture is also important as silt and clay can promote the formation of organicmineral complexes in the soil layer. In this study, the percentage of sand was lower in the plantation of $A$. lebbeck (77.57-64.63\%) compared to UPD site (78.27-70.57\%), while the plantations of other three species (A. procera, T. grandis and D. strictus) showed higher range than UPD site at $0-50 \mathrm{~cm}$ spoil depth (Fig. 1c). Opposite to sand, percentage of silt was higher in the plantation of $A$. lebbeck compared to
UPD plot at $0-50 \mathrm{~cm}$ spoil depth (Fig. 1d). However, corresponding values varied among plantations in the following order: A. lebbeck (14.10$13.60 \%)<D$. strictus $(9.13-6.30 \%)<\mathrm{UPD}(7.58-$ $9.92 \%)<A$. procera $(6.31-12.15 \%)<T$. grandis $(5.53-$ $9.97 \%$ ) (Fig. 1d). Whereas clay percentage also varied among plantations, being highest in UPD plot $(22.03 \%)$ at $30-40 \mathrm{~cm}$ spoil depth while lowest in A. lebbeck $(8.33 \%)$ at $0-10 \mathrm{~cm}$ spoil depth (Fig. 1e). However, values recorded at $0-50 \mathrm{~cm}$ spoil depth were substantially lower in the plantation of A. lebbeck compared to UPD plots followed by $T$. grandis, D. strictus and $A$. procera (Fig. 1e). Therefore, statistical analysis (ANOVA) exhibited significant differences due to species and spoil depth for sand, silt and clay, while interactions (species $\times$ spoil depth) were significant for silt and clay only (Table 1).

The particle size of soils on mined sites was generally finer relative to UPD sites, and clay tended to be translocated to lower horizons by soil formation over time (Wali 1999; Ciarkowska et al., 2017). It is one of the most permanent soil physical properties, and is a major factor governing the successful reestablishment of vegetation on reclaimed slopes (Toy and Shay 1987). Nevertheless, it influences soil moisture relations, erosion characteristics, bulk densities, nutrient contents, and nutrient availability. In the fresh mine spoil corresponding contents (sand, silt and clay) were reported as about $80 \%, 9 \%$ and $11 \%$, respectively from the same site area (Singh et al., 2004a ; Dolhopf et al., 1981) suggested that mine soils with clay contents greater than $40 \%$ might adversely affect reclamation success due to low permeabilities and infiltration rates, structural problems, and compaction problems. They also reported that mine soils with the sand content of greater than $70 \%$ might not contain sufficient water for plant production. Soils with high contents of medium fine and very fine sands are very susceptible to wind erosion and soils with a high proportion of very fine sands and silts are susceptible to erosion by water (Hausenbuiller 1981). However, in present study, significant variations due to soil texture (sand, silt and clay) among these plantations indicated that these species have capability to change the spoil texture after their establishment and growth in coming periods.

\section{Effect of Chemical Characters on mine spoil $\mathrm{PH}$ ranges of mine spoil}

The $\mathrm{pH}$ values in the plots of different plantations including UPD at $0-50 \mathrm{~cm}$ spoil depth exhibited a neutral range (6.22-7.33) (Fig. 1f). However, ANOVA indicated significant differences due to species only (Table 1). Of all the chemical measurements taken, $\mathrm{pH}$ is most useful in mine rehabilitation studies as it is readily determined and is an overall indicator of the nutrient status of the soil. Slight acid to slight alkaline $\mathrm{pH}$ provides 
optimum plant growth conditions, because nutrient availability is greater within this range (Hausenbuiller 1981). Low pH inhibits plant growth because toxic elements such as $\mathrm{Al}, \mathrm{Fe}, \mathrm{Mn}$ may be present in soil solution at $\mathrm{pH}$ below 4.0 thereby limiting the successful establishment of some plant species (Barnhisel and Massey 1969; Bradshaw 1997a,b). In the present plantations, $\mathrm{pH}$ was not the problem as it is reported from other mining habitats elsewhere, for example lignite mine spoils at Czech (Sourkova et al., 2005) and Germany (Rumpel et al., 2000).

Total exchangeable cations of mine spoil Concentrations of exchangeable cations ( $\mathrm{Ca}, \mathrm{Mg}, \mathrm{K}$ and $\mathrm{Na}$ ) among plantations did not significantly vary due to spoil depth (Figs. 2a-d; Table 1). However, the values were substantially higher in all plantations than UPD site at surface layer $(0-10 \mathrm{~cm})$ (Figs.2a-d). Highest concentration of $\mathrm{Ca}$ was found in the surface layer $(0-10 \mathrm{~cm})$ of $T$. grandis $(0.042 \mathrm{c}$

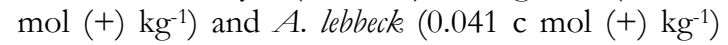

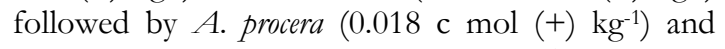
lowest in D. strictus $\left(0.015 \mathrm{c} \mathrm{mol}(+) \mathrm{kg}^{-1}\right)$ plantation (Fig. 2a). However, a decreasing trend appeared in the values of all plantations from progressively down profile from $0-50 \mathrm{~cm}$ spoil depth but there was not any uniformity developed as a whole. Therefore due to this, effect of spoil depth was not significant while effect of species and interaction (species $\times$ spoil depth) were significantly different (Table 1). In case of $\mathrm{Mg}$, all species showed a less variation across spoil depth. However, highest concentration was found in $A$. lebbeck $(0.017 \mathrm{c} \mathrm{mol}$ $\left.(+) \mathrm{kg}^{-1}\right)$ and lowest in D. strictus $(0.005 \mathrm{c} \mathrm{mol}(+)$ $\left.\mathrm{kg}^{-1}\right)$ at surface layer $(0-10 \mathrm{~cm})$ (Fig. 2b). While in case of $\mathrm{K}$ concentration, all plantations showed a decreasing trend with spoil depth but the values were in less variation even from UPD plots. ANOVA did not indicate significant differences either by species or by spoil depth (Fig. 2c; Table 1). Nevertheless, among plantations, greater concentration was found in A. lebbeck $(0.004 \mathrm{c} \mathrm{mol}$ (+) $\left.\mathrm{kg}^{-1}\right)$ and $T$. grandis $\left(0.004 \mathrm{c}\right.$ mol (+) $\left.\mathrm{kg}^{-1}\right)$ followed by $A$. procera and $D$. strictus at $0-10 \mathrm{~cm}$ spoil depth (Fig. 2c).

$\mathrm{Na}$ concentrations varied in the range of 0.068 to $0.017 \mathrm{c} \mathrm{mol}(+) \mathrm{kg}^{-1}$ in $A$. lebbeck, 0.027 to $0.017 \mathrm{c}$ $\mathrm{mol}(+) \mathrm{kg}^{-1}$ in $A$. procera, 0.045 to $0.016 \mathrm{c} \mathrm{mol} \mathrm{(+)}$ $\mathrm{kg}^{-1}$ in $T$. grandis and 0.059 to $0.018 \mathrm{c} \mathrm{mol}(+) \mathrm{kg}^{-1}$ in D. strictus plantation at $0-50 \mathrm{~cm}$ spoil depth (Fig. 2d). ANOVA indicated significant differences due to species only (Table 1 ).

Table 1. Summary of ANOVA for the effect of species and spoil depth and species $\times$ spoils depth interaction on physico-chemical characters of mine spoil.

\begin{tabular}{lcccccc}
\hline \multirow{2}{*}{ Soil characters } & \multicolumn{2}{c}{ Species } & \multicolumn{2}{c}{ Depth } & \multicolumn{2}{c}{ Species $\times$ depth } \\
\cline { 2 - 7 } & $\mathbf{F 4 , 5 0}$ & $\mathbf{P}$ & $\mathbf{F 4 , 5 0}$ & $\mathbf{P}$ & \multicolumn{2}{c}{ F16, 50 } \\
\hline pH & 39.024 & 0.000 & 2.192 & 0.083 & 0.611 & 0.860 \\
Bulk density & 1.841 & 0.136 & 1.652 & 0.176 & 0.231 & 0.999 \\
Water holding capacity & 23.578 & 0.000 & 16.074 & 0.000 & 0.629 & 0.845 \\
Sand & 41.842 & 0.000 & 29.633 & 0.000 & 0.905 & 0.568 \\
Silt & 85.092 & 0.000 & 4.339 & 0.004 & 3.989 & 0.000 \\
Clay & 19.442 & 0.000 & 15.693 & 0.000 & 2.208 & 0.017 \\
Organic C & 310.689 & 0.000 & 354.22 & 0.000 & 36.352 & 0.000 \\
Kjeldahl N & 101.141 & 0.000 & 186.388 & 0.000 & 15.785 & 0.000 \\
Total P & 10.099 & 0.000 & 42.696 & 0.000 & 4.029 & 0.000 \\
C: N ratio & 21.459 & 0.000 & 2.662 & 0.043 & 2.938 & 0.002 \\
C: P ratio & 47.815 & 0.000 & 22.689 & 0.000 & 6.868 & 0.000 \\
Ca & 3.795 & 0.009 & 2.350 & 0.067 & 2.702 & 0.004 \\
Mg & 2.381 & 0.064 & 2.470 & 0.057 & 2.648 & 0.004 \\
K & 0.326 & 0.860 & 1.273 & 0.293 & 1.438 & 0.163 \\
Na & 3.631 & 0.011 & 1.970 & 0.113 & 3.040 & 0.001 \\
\hline
\end{tabular}

Evidently, these cations reported in fresh mine spoils from same area were in lower concentration as from all plantations (Singh et al., 2004a), indicating that values were in substantial amount due to vegetation effect. In the evidence of this, several studies either from mined or un-mined areas showed that the amount of exchangeable cations in the soil can be positively influenced by the tree species composition (Van Breeman et al., 1997; Finzi et al., 1998a; Mohr et al., 2005) or parent materials of the problem sites (Vimmerstedt et al., 1989; Wali 1999). Moreover, this has mainly been attributed to differences in the $\mathrm{pH}$ values (Finzi et al., 1998a), leaf chemistry (Filcheva et al., 2000) and decomposability of the plant materials (Mohr et al., 2005). In our study, however, $\mathrm{pH}$ was consistent in all plantations with respect to spoil depth even in UPD site; therefore, attribution by $\mathrm{pH}$ might be same. But litter chemistry and their decomposition rates substantially varied with planted species. Evidently, a wide variation in the mean relative decomposition rate of the leaf litters of all plantation species was reported (Singh, 1999). $A$. lebbeck showed highest mean relative decomposition rate $\left(2.42 \mathrm{mg} \mathrm{g}^{-1} \mathrm{~d}^{-1}\right)$ followed by D. strictus $(2.28 \mathrm{mg}$ $\left.\mathrm{g}^{-1} \mathrm{~d}^{-1}\right), T$. grandis $\left(2.20 \mathrm{mg} \mathrm{g}^{-1} \mathrm{~d}^{-1}\right)$ and $A$. procera (2.12 $\mathrm{mg} \mathrm{g}^{-1} \mathrm{~d}^{-1}$ ) (Singh 1999). Perhaps due to this reason, plantation of $A$. lebbeck reflected greater concentration of all exchangeable cations at surface layer in the mine spoils.

\section{Total Carbon, Nitrogen, Phosphorus and their ratios of mine spoil}

Soil organic C, kjeldahl N, total $\mathrm{P}$ and their ratios are presented in Figs. 3a-e. These contents showed a decreasing trend with increasing spoil depth, and 
were significantly higher in all plantations compared to the UPD site (Table 1). Among plantations, however at surface layer $(0-10 \mathrm{~cm})$, highest $\mathrm{C}, \mathrm{N}$ and $\mathrm{P}$ contents were found in $A$. lebbeck (C: 7.25 $1.63 \mathrm{~g} \mathrm{~kg}^{-1}$; N: 0.70-0.16 $\mathrm{g} \mathrm{kg}^{-1}$ and P: $0.19-0.13 \mathrm{~g} \mathrm{~kg}^{-}$ $\left.{ }^{1}\right)$ and lowest in T. grandis (2.5-0.91 $\mathrm{g} \mathrm{kg}^{-1}, 0.25-0.11$ $\mathrm{g} \mathrm{kg}^{-1}$ and $0.18-0.08 \mathrm{~g} \mathrm{~kg}^{-1}$ ), respectively (Figs. 3a-c). Although both $\mathrm{C}$ : $\mathrm{N}$ and $\mathrm{C}$ : $\mathrm{P}$ ratios did not show any trend according to the depth or species, their values were significantly different due to species and spoil depth (Figs. 3d-e; Table 1). Percent increases in soil $\mathrm{C}$ and $\mathrm{N}$ contents in all plantations relative to that in UPD were calculated. Among species, plantation of $A$. lebbeck attained $437.0 \%$ greatest $C$ and $335.6 \% \mathrm{~N}$ from UPD followed by $D$. strictus (398.5\% C and $318.8 \% \mathrm{~N})$, A. procera $(211.9 \% \mathrm{C}$ and $243.8 \% \mathrm{~N})$ and $T$. grandis $(85.2 \% \mathrm{C}$ and $55.0 \%$ $\mathrm{N})$, respectively at surface layer $(0-10 \mathrm{~cm})$ of mine spoil. Corresponding increments were reflected a declining trend with increasing spoil depth (0-50 $\mathrm{cm})$ almost in all plantations. Therefore, in this study, higher soil organic $\mathrm{C}$ and $\mathrm{N}$ values were found in following order: A. lebbeck $>D$. strictus $>$ A. procera $>T$. grandis. In conformity with this, a high level of their respective primary productivity and biomass accumulation as reported in Singh (1999), Singh and Singh (1999), Singh et al., (2004b). Like N, P is an essential element for plant growth and is one of limiting nutrients in colliery spoils (Bloomfield et al., 1982). In the present study, total $\mathrm{P}$ concentration under $0-10 \mathrm{~cm}$ spoil depth was $109.8 \%$ greater in $A$. lebbeck, $112.0 \%$ in $A$. procera, $97.8 \%$ in T. grandis and $52.2 \%$ in D. strictus than that under UPD site. However, such changes concomitantly declined with increase of spoil layer up to $20-30 \mathrm{~cm}$ while from 30 to $50 \mathrm{~cm}$ a little difference was found in the mean concentrations of all plantations including UPD, indicating that the effect of plant species as well as spoil depth on total $\mathrm{P}$ are not a key factors to augment in the deeper layer of soil.

$\mathrm{C}$ : $\mathrm{N}$ ratios indicate the trend toward rehabilitation of mined sites. The $\mathrm{C}-\mathrm{N}$ relationship is based on the relative fluxes of carbohydrates and nitrogenous compounds during the mineralization of organic matter over time, and its importance in reflecting the dynamics of soil systems has been emphasized in several studies on mine spoil (Wali 1999; Filcheva et al., 2000; Frouz et al., 2001; Bradshaw 1997a, b) as well as from unmined sites (Van Breeman et al., 1997; Finzi et al., 1998b). C: $\mathrm{N}$ ratios can be a useful indicator to assess the restoration dynamics of mined systems over time. Wali (1999) reported same ratios in widest range for 1-year old (5-40), while limited range (10-15) for 45-year old naturally vegetated coalmine spoil, comparable to unmined sites. In earlier study, these ratios were significantly changed with stand age, evidently showing an agerelated trend and confirming vegetation effect from young stage (Singh et al., 2004a). However, in present study, expressed higher range from UPD in the following order: $A$. lebbeck $>D$. strictus $>T$. grandis $>A$. procera, but did not show any trend with respect to spoil depth. Another ratios (C: $\mathrm{P})$, which reflect changes in both total organic $\mathrm{C}$ and total $\mathrm{P}$, however, did not evidently change like $\mathrm{C}$ : $\mathrm{N}$ ratios; perhaps the mechanisms responsible $\mathrm{C}$ : $\mathrm{P}$ ratios might vary according to the different levels of ecosystem function and species to species.

On the other hand, productivity of a soil and the rate at which soil properties change has great importance to the long-term success of reclamation and other land use management systems (Roberts et al., 1988; Akala and Lal, 2000). Changes in soil properties due to plantation age are initially very rapid and subsequently slower rates are observed; moreover, development of equilibrium may vary between 25-50 years and is seldom seen in short term studies of mine spoil restoration (Anderson 1977). In conformity with this, an earlier study on the same site and plantation species reported a continued increase with stand age in microbial biomass C: total $\mathrm{C}$ ratios, indicating that equilibrium state is yet to be achieved (Singh et al., 2004a). In the early period of establishment of the plantations, there was a progressive build-up of organic matter and nutrients because of the faster growth and high allocation of foliage component in the total biomass and production at stand level (Singh and Singh 1999; Singh et al., 2004b). In this study, two species (A. lebbeck and $A$. procera) are leguminous in nature, but $A$. lebbeck exhibited better contribution in developing organic matter especially $\mathrm{N}$ capital in the soil of mine spoils. While a non-leguminous species (D. strictus, a woody grass) showed a remarkable role in the build-up of organic matter through heavy deposition of litter fall (10.7 $\mathrm{t} \mathrm{ha}^{-1}$ year-1 at 5 -year age) on plantation floor and greater amounts of fine roots $\left(1.40 \mathrm{t} \mathrm{ha}^{-1}\right)$ in redeveloping soil of mine spoil (Singh and Singh 1999). Being leguminous in nature, $A$. procera did not pay apparent role like $A$. lebbeck even as $D$. strictus, indicating that some nonleguminous species can contribute better performance to improve soil characters during rehabilitation of any degraded ecosystems. 

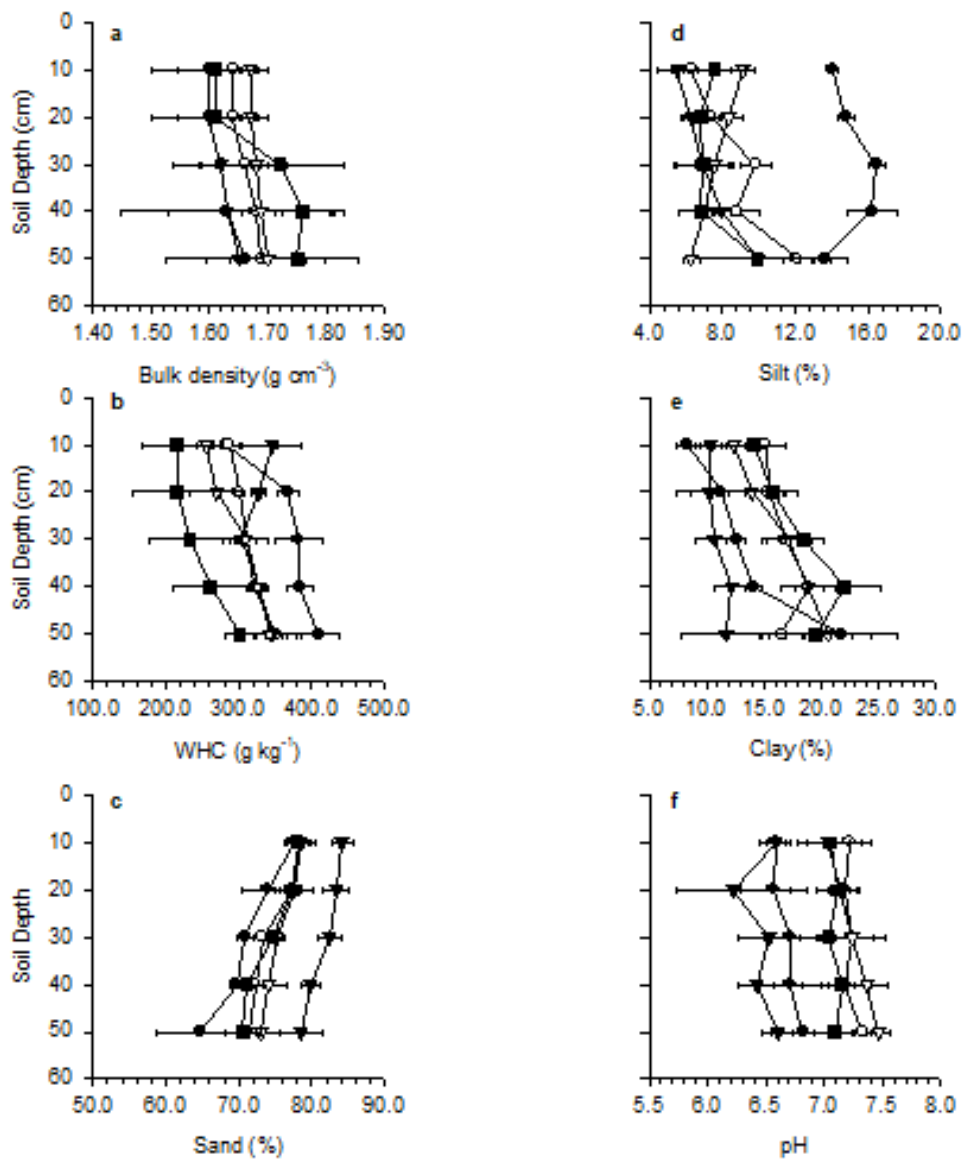

$\rightarrow$ A. lebbeck $\rightarrow$ - A. procera $\rightarrow T$. grandis $\rightarrow-D$. sbichus $\rightarrow-$ Unplanted Dump

Figure 1. Soil bulk density (a), water holding capacity (b), textural composition such as sand (c), silt (d), clay (e) and $\mathrm{pH}$ (e) values under unplanted dump and five-year-old plantations of certain woody species raised on coalmine spoil. Each point in each observation represents the mean of three replicates. Error bars reflect 1 standard deviation.
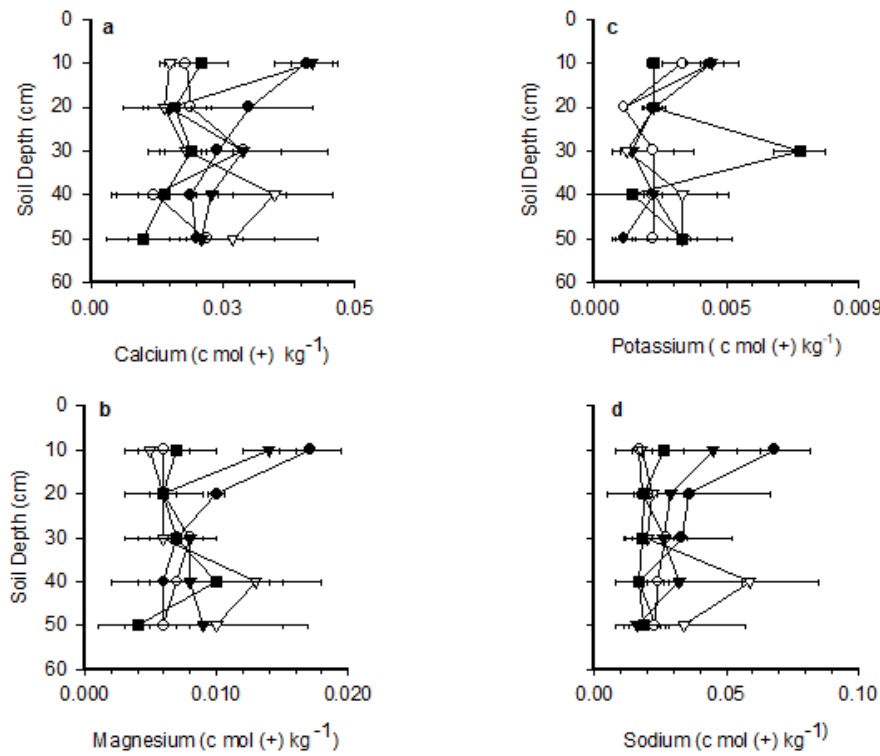

$\rightarrow$ A. lebbeck $\rightarrow-$ A. procera $\rightarrow T$. grandis $\rightarrow-D$. strictus $\rightarrow-$ Unplanted Dump

Figure 2. Concentrations of exchangeable cations $\mathrm{Ca}$ (a), $\mathrm{Mg}$ (b), $\mathrm{K}$ (c) and $\mathrm{Na}$ (d) under unplanted dump and five-year-old plantations of certain woody species raised on coalmine spoil. Each point in each observation represents the mean of three replicates. Error bars reflect 1 standard deviation. 

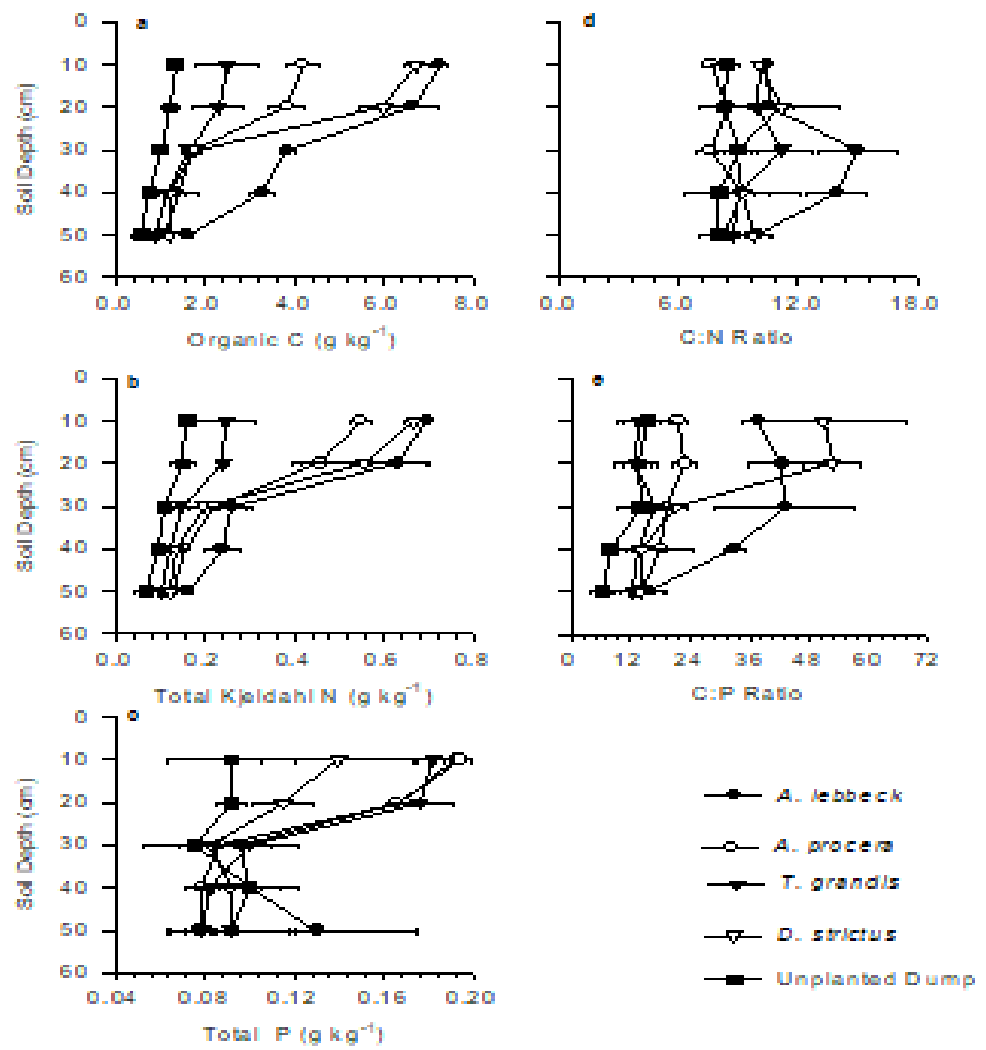

Figure 3. Total soil organic $\mathrm{C}(\mathrm{a})$, total kjeldahl $\mathrm{N}(\mathrm{b})$, total $\mathrm{P}(\mathrm{c})$ and their ratios (C: $\mathrm{N}$ and $\mathrm{C}: \mathrm{P}$ ) (d and e) under unplanted dump and certain indigenous woody plantations on coalmine spoil. Each point in each observation represents the mean of three replicates. Error bars reflect 1 standard deviation.

\section{Conclusions}

In comparison to naturally vegetated dump, all plantations showed substantial effects to improving physico-chemical qualities of mine spoil within a short period except for soil bulk density. Among plantations, physical characters were maximally improved by $A$. lebbeck, and followed by D. strictus and A. procera. For example, silt and clay composition in soil texture with respect to spoil depth was better in $A$. lebbeck plantation. Not standing with this, in case of chemical characters, plantation of $A$. lebbeck showed greater values in terms of qualities and quantities in the assessment of spoil characteristics such as total $\mathrm{C}, \mathrm{N}, \mathrm{P}$ and exchangeable concentration followed by $D$. strictus, $A$. procera and $T$. grandis, respectively.

In conclusion, each species has different capacity to improve soil characters during mine spoil restoration. But permanent rehabilitation of coalmine spoil requires the presence of many species. For example, slow growing non-leguminous timber species ( $T$. grandis), fast growing woody grass (D. strictus) and N-fixing Albizia (A. lebbeck, A. procera) planted in mixed stands can be more potential as for productivity and lead to faster soil redevelopment at least at young stage of rehabilitation process. Therefore, the effects involved in mixed stands are worthwhile further study.

\section{Acknowledgements}

Author is thankful to the University Grants Commission, Government of India, for financial assistance through Major Research Project (MRP) to commence Ecological Research on degraded ecosystems.

\section{References}

1. Akala VA and Lal R, Potential of mine land reclamation for soil organic carbon sequestration in Ohio, Land Degradation and Development, 2000, 11, 289-297.

2. Allen SE, Grimshaw HM and Rowland AP, Chemical analysis. In: Moore, P.D., Chapman, S.B. (Eds.), Methods in Plant Ecology. Blackwell Scientific Publications, 1986, pp. 285-344.

3. Anderson DW, Early stages of soil formation on glacial till mine spoils in a semi-arid environment, Geoderma, 1977, 19, $11-19$.

4. Barnhisel RI and Massey HF, Chemical, mineralogical and physical properties of Eastern Kentucky acid-forming coal spoil materials, Soil Science, 1969, 108, 367-372.

5. Bending NAD and Moffat AJ, Tree performance on mine spoils in the South Wales coalfield, Journal of Applied Ecology, 1999, 36, 784-797.

6. Bloomfield, HE, Handley JF and Bradshaw AD, Nutrient deficiencies and the aftercare of reclaimed derelict land, Journal of Applied Ecology, 1982, 19, 151-158.

7. Bradshaw $\mathrm{AD}$ and Huttel RF, Future mine site restoration involves a broader approach, Ecological Engineering, 2001, 17, 87-90.

8. Bradshaw $\mathrm{AD}$, Restoration of mined lands - using natural processes, Ecological Engineering, 1997a, 8, 255-269.

9. Bradshaw $\mathrm{AD}$, The importance of soil ecology in restoration science. In: Restoration Ecology and Sustainable Development (K.M. Urbanska, N.R. Webb and P.J. Edwards, eds.), 1997b, pp. 33-65. Cambridge University Press, Cambridge.

10. Bradshaw AD, The use of natural process in reclamation advantages and difficulties, Landscape and Urban Planning, 2000, 51, 89-100. 
11. Ciarkowska K, Organic matter transformation and porosity development in non-reclaimed mining soils of different ages and vegetation covers: a field study of soils of the zinc and lead ore area in SE Poland, Journal of Soils Sediments, 2017, DOI $10.1007 /$ s11368-017-1678-4.

12. DeLong C, Skousen J and Pena-Yewtukhiw E, Bulk Density of Rocky Mine Soils in Forestry Reclamation, Soil \& Water Management \& Conservation, 2011, doi:10.2136/sssaj2011.0380.

13. Dolhopf DJ, Goering JD, Levine CJ, Bauman BJ, Hedberg D.W and Hodder RL, Selective placement of strip mine overburden in Montana, 1981, Final Report to the U.S. Bureau of Mines, Contract. HO262032.

14. Filcheva E, Noustorova M and Gentcheva-Kostadinova Sv. and Haigh M], Organic accumulation and microbial action in surface coal-mine spoils, Pernik, Bulgaria. Ecological Engineering, 2000, 15, 1-15

15. Finzi AC, Canham CD and Van Breeman N, Canopy tree- soil interactions within temperate forests: species effects on $\mathrm{pH}$ and cations, Ecological Applications. 1998a, 8, 447-454.

16. Finzi AC, Van Breeman, $\mathrm{N}$ and Canham CD, Canopy tree- soil interactions within temperate forests: species effects on soil carbon and nitrogen, Ecological Applications, 1998b, 8, 440446.

17. Fisher RF, Amelioration of degraded rain forest soils by plantations of native trees. Soil Science Society of America Journal, 1995, 59, 544-549.

18. Frouz J, Effects of Soil Development Time and Litter Quality on Soil Carbon Sequestration: Assessing Soil Carbon Saturation with a Field Transplant Experiment along PostMining Chronosequence, Land Degradation \& Development, 2017, 28, 664-672.

19. Frouz J, Keplin B, Pizl V, Tajovsky K, Stary J, Lukesova A, Novakova A, Balík V, Hanel L, Matema J, Duker C, Chalupsky $\mathrm{J}$, Rusek J and Heinkele T, Soil biota and upper soil laver development in two contrasting post-mining chronosequences, Ecological Engineering, 2001, 17, 275-284.

20. Hausenbuiller RL, Soil Science, Principles and Practices. 1981, William C. Brown, Dubuque, Iowa.

21. Jackson ML, Soil Chemical Analysis. 1958, Prentice-Hall, Englewood, Cliffs, NJ.

22. Jozefowska A, Pietrykowski M, Wos B and Frouz J, The effects of tree species and substrate on carbon sequestration and chemical and biological properties in reforested post-mining soils, Geoderma, 2017, 292, 9-16.

23. Liu X, Bai Z, Zhou W, Cao Y and Zhang G, Changes in soil properties in the soil profile after mining and reclamation in an opencast coal mine on the Loess Plateau, China, Ecological Engineering, 2017, 98, 228-239.

24. Mohr D, Simon M and Topp W, Stand composition affects soil quality in oak stands on reclaimed and natural sites, Geoderma, 2005, 129, 45-53.

25. Piper CS, Soil and Plant Analysis. 1944, Inter-Science Publications, Inc., New York.

26. Roberts JA, Daniels WL, Bell JC and Burger, JA, Early stages of mine soil genesis in a southwest Virginia spoil lithosequence, Soil Science Society of America Journal, 1988, 52, 716-723.

27. Rumpel C, Kogel-Knabner I, Knicker H and Huttl, RF, Composition and distribution of organic matter in physical fractions of a rehabilitated mine soil rich in lignite-derived carbon, Geoderma, 2000, 98, 177-192.

28. Russell RS, Plant Root Systems, 1977, McGraw Hill, London.

29. Singh AN and Singh JS, Biomass, net primary production and impact of bamboo plantation on soil redevelopment in a dry tropical region, Forest Ecology and Management, 1999, 119, 195-207.

30. Singh AN, Raghubanshi AS and Singh JS, Comparative performance and restoration potential of two Albiria species planted on mine spoil in a dry tropical region, India, Ecological Engineering, 2004b, 22, 123-140.

31. Singh AN, Raghubanshi AS and Singh JS, Impact of native tree plantations on mine spoil in a dry tropical environment, 2004a, Forest Ecology and Management, 187, 49-60.

32. Singh AN, Raghubanshi AS and Singh JS, Plantation as a tool for mine spoil restoration, Current Science, 82, 2002, 14361441.

33. Singh AN, Structure, functioning and impact of young plantations of four native woody species on coal mine spoil, 1999, Ph.D. Thesis, Banaras Hindu University, India.

34. Singh JS, Singh KP and Jha AK, (eds.), An Integrated Ecological Study on Revegetation of Mine Spoil: Concepts and Research Highlights. Interim Report of an $\mathrm{S} \& \mathrm{~T}$ project sponsored by the Ministry of Coal, Govt. of India, 1995, Department of Botany, Banaras Hindu University, Varanasi.

35. Sourkova M, Frouz J and Santruckova H, Accumulation of carbon, nitrogen and phosphorus during soil formation on alder spoil heaps after brown-coal mining, near Sokolov (Czech Republic), Geoderma. 2005, 124, 203-214.

36. SPSS Inc., 2014. SPSS/PC for the IBM PC/XT/AT Chicago, II.

37. Sutton P and Dick WA, Reclamation of acidic mined lands in humid areas. Advances in Agronomy, 1987, 41, 377-405.

38. Toy TJ and Shay D, Comparison of some soil properties on natural and reclaimed hillslopes, Soil Science, 1987, 143, $264-$ 277.

39. Van Breeman N, Finzi AC and Canham CD, Canopy tree soil interactions within temperate forests: effects of soil element composition and texture on species distribution, Canadian Journal of Forest Research, 1997, 27, 1110-1116.

40. Vega FA, Covelo EF and Andrade ML, Limiting factors for reforestation of mine spoils from Galicia (Spain), Land Degradation \& Development, 2005, 16, 27-36

41. Vimmerstedt JP, House MC, Larson MM, Kasile JD and Bishop, BL, Nitrogen and carbon accretion on Ohio coal mine spoils: Influence of soil-forming factors, Landscape and Urban Planning, 1989, 17, 99-111.

42. Wali MK, Ecological succession and the rehabilitation of disturbed ecosystems, Plant and Soil, 1999, 213, 195-220.

43. Zhou W, Yanga K, Baia Z, Cheng $\mathrm{H}$ and Liu F, The development of topsoil properties under different reclaimed land uses in the Pingshuo opencast coalmine of Loess Plateau of China, Ecological Engineering, 2017, 100, 237-245.

\section{Cite this article as:}

A.N. Singh: Spoil characteristics under five years old native woody plantations and unplanted dump in dry tropical environment, India Annals of Plant Sciences 6.11 (2017) pp. 1763 1771.

doi: http://dx.doi.org/10.21746/aps.2017.6.11.7 